Original Research Paper

\title{
ANALISIS PENGALAMAN PSIKOLOGIS PERAWAT DALAM MENANGANI PASIEN COVID-19
}

\section{Dinda Nur Asri Mutiara Ramadhani*, Oedojo Soedirham}

\section{Departemen Promosi Kesehatan dan Ilmu Perilaku, Fakultas Kesehatan Masyarakat, Universitas} Airlangga, Surabaya Indonesia

\section{Email Corresponding: \\ dinda.nur.asri- \\ 2017@fkm.unair.ac.id}

Page : $158-167$

Kata Kunci :

Covid-19,

Perawat,

Pengalaman Psikologis

Keywords:

Covid-19

Nurse

Psychological Experience

\section{ABSTRAK}

Pandemi covid 19 mengejutkan dunia ketika ditemukannya kasus pneumonia misterius yang berasal dari Kota Wuhan Tiongkok pada tanggal 31 Desember 2019. World Health Organization (WHO) memberikan nama virus baru tersebut Severa Acute Respiratory Syndrome Coronavirus-2 (SARS-Cov-2) dan nama penyakitnya sebagai Corona Virus Disease (Covid-19). Negara Indonesia masuk dlaam peringkat ke-19 dengan kasus Covid-19 terbanyak di dunia (Worldometers,2020). Tenaga kesehatan salah satunya perawat merupakan salah satu garda terdepan dalam menangani wabah Covid-19. Penyedia layanan kesehatan, khususnya perawat tidak hanya mengalami peningkatan beban kerja tetapi juga perubahan psikologis yang berdampak pada kesehatan mental perawat di seluruh dunia berupa burnout, kecemasan, depresi, dan ketakutan terhadap stigma dan diskriminasi masyarakat (International Council of Nurses, 2020).

\section{ABSTRACT}

The COVID-19 pandemic shocked the world when a mysterious pneumonia case was discovered from Wuhan City, China on December 31, 2019. The World Health Organization (WHO) named the new virus Severa Acute Respiratory Syndrome Coronavirus-2 (SARS-Cov-2) and the name of the disease. as Corona Virus Disease (Covid-19). Indonesia is ranked 19th with the most Covid-19 cases in the world (Worldometers, 2020). Health workers, including nurses, are at the forefront of dealing with the Covid-19 outbreak. Health care providers, especially nurses, are not only experiencing an increase in workload but also psychological changes that have an impact on the mental health of nurses around the world in the form of burnout, anxiety, depression, and fear of stigma and community discrimination (International Council of Nurses, 2020).

\section{Published by:}

Tadulako University,

Managed by Faculty of

Medicine. Email:

healthytadulako@gmail.com

Phone (WA): +6285242303103

Address:

Jalan Soekarno Hatta Km. 9.

City of Palu, Central Sulawesi, Indonesia sebagai pandemi global (WHO,2020). Covid19 pertama kali diumumkan pada 11 Maret 2020, virus ini telah menginfeksi populasi besar di berbagai negara. Covid-19 merupakan jenis pneumonia baru yang muncul dan dilaporkan sejak akhir Desember 2019 di Kota 
Wuhan, China dan telah menyebar dengan cepat ke negara-negara lain di seluruh dunia ${ }^{1}$. Pada 26 Juni 2020 sebanyak 9.473.214 kasus secara global dengan 484.249 kematian (CFR $5,1 \%$ ) di 215 negara terinfeksi, Indonesia dengan 51.427 kasus dengan 2.683 kematia (CFR 5,2\%) lebih tinggi dari global. Seiring dengan meningkatnya jumlah kasus Covid-19, hal ini menjadi masalah besar bagi tenaga medis khususnya perawat, sebagai garda terdepan dalam menangani pasien Covid-19, hal ini membuat perawat cenderung lebih berisiko terpapar karena mereka merawat pasien secara langsung ${ }^{1}$.

Kontak perawat yang sering dengan pasien Covid-19, apabila tanpa Alat Perlindungan Diri (APD) yang tepat atau APD yang tidak sesuai standar kesehatan mengakibatkan kerakutan, stres, dan kecemasan yang berlebihan. Prevalensi masalah kesehatan mental telah ditemukan dalam beberapa penelitian. Dalam sebuah studi petugas kesehatan garis depan di Cina, menemukan bahwa 50\% mengalami depresi, $45 \%$ mengalami kecemasan dan 34\% mengalami insomnia. Sedangkan untuk di Indonesia berdasarkan hasil penelitian FIK-UI dan IPKJI (2020) respon yang paling sering muncul pada perawat ialah perasaan cemas dan tegang sebanyak $70 \%$.

Respon psikologi yang timbul dan merugikan diantaranya yaitu adanya perasaan ketakutan akan penularan dan penyebaran virus ke keluarga, teman dan antar teman sejawat lainnya ${ }^{2}$. Hasil penelitian yang dilakukan oleh Sun et al., (2020) menunjukkan perawat yang merawat pasien Covid-19 mengalami adanya stress akibat dari ketakutan berada di ruang perawatan dengan tekanan negatif dan merasakan kecemasan akan menularkan virus tersebut keanggota keluarga atau lingkungan sekitarnya ${ }^{3}$.

Stres yang dialami perawat tambah berat saat melihat pasien yang dirawat dalam kondisi meninggal dunia. Selain itu, kecemasan juga dialami karena kelelahan akibat meningkatnya jumlah jam bekerja ${ }^{4}$.

Beberapa penelitian sebelumnya menunjukkan bahwa pengalamn psikologis yang dialami perawat berbeda-beda selama pandemi Covid-19,5,3. Oleh karena itu, eksplorasi mendalam tentang pengalaman Psikologis perawat baik yang menangani pasien Covid-19 secara langsung maupun tidak. Oleh karena itu perawat harus melakukan upaya untuk mengurangi ketakutan tersebut. Melihat masalah diatas maka saya tertarik untuk melakukan studi literatur review tentang "Analisis Pengalaman Psikologis Perawat Dalam Menangani Pasien Covid-19”.

\section{METODE PENELITIAN}

Penulis membuat penelitian dalam bentuk literature review dengan mengidentifikasi, evaluasi dan interpretasi hasil penelitian sebelumnya yang berkaitan dengan judul atau topik yang diteliti. Literature review merupakan metode penelitian yang bertujuan untuk merangkum hasil penelitian primer sehingga bisa menyajikan fakta komprehensif.

Pencarian topik dan kepustakaan untuk penentuan judul. (2) Pencarian kepustakaan untuk isi dan hasil. (3) Mmebandingkan hasil dari amsing-masing kepustakaan dalam satu tabel. (4) Menarik kesimpulan berdasarkan hasil yang didapat. Artikel didapatkan dari pencarian database seperti Google Scholar, Pubmed. Kriteria artikel yang digunakan dalam penelitian ini dipilih berdasarkan kriteria inkluasi yang sudah dibuat oleh epenltii yakni artikel tersedia dalam bentuk full text, memiliki kesesuaian isi dan tujuan dari studi yang dilakukan. Kata kunci yang digunakan dalam pencarian artikel ataupun jurnal adalah " Covid$19 "$ + "Nurse" + "Psychological Experience". 


\section{HASIL}

Hasil kajian dalam penelitian ini dengan mnegkaji 20 artikel terkait yang membahas tentang pengalaman psikologi perawat selama pandemi Covid-19. Artikel-artikel ini menjelaskan pengalaman psikologis perawat dalam menghadapi pasien Covid-19, antara lain kecemasan, stres, ketakutan, insomnia, dll.

\section{Kecemasan}

Respon psikologis kecemasan pada perawat dikategorikan menjadi tiga tingkatan, antara lain: tidak ada kecemasan (skor 0-6), kecemasan ringan sampai sedang (skor 7-13) dan kecemasan berat (skor $14)^{6,7}$. Tingkat kecemasan perawat selama pandemi COVID-19 secara signifikan lebih tinggi daripada tingkat kecemasan Middle East Respiratory Syndrome- Coronavirus (MERS-CoV) atau flu lainnya ${ }^{8}$. Kecemasan yang dirasakan perawat lebih tinggi dibandingkan tenaga kesehatan lainnya (40\% vs $15 \%(\mathrm{p}=0,001)^{4,9}$.

\section{Depresi}

Tenaga kesehatan sebagai garda depan yang terlibat langsung dalam penanganan pasien COVID-19 berpotensi lebih rentan terhadap gangguan psikologis, salah satunya gejala depresi ${ }^{7,10}$. Kesehatan jiwa yang dialami perawat diantaranya $39,1 \%$ mengalami gangguan psikologis yaitu depresi ${ }^{4}$. Tenaga kesehatan sebagai garda depan yang terlibat langsung dalam penanganan pasien COVID-19 berpotensi lebih rentan terhadap gangguan psikologis, salah satunya gejala depresi ${ }^{1,10}$. Kesehatan jiwa yang dialami perawat diantaranya $39,1 \%$ mengalami gangguan psikologis yaitu depresi ${ }^{4}$. Faktor pribadi, dalam beberapa penelitian disebutkan bahwa jenis kelamin perempuan paling banyak mengalami masalah kesehatan mental dan tekanan psikologis jauh lebih tinggi, jika dibandingkan dengan laki- laki ${ }^{11}$. Perawat yang mengalami gejala depresi dikategorikan menjadi tiga yaitu: gejala depresi normal, ringan, sedang hingga berat $^{6,12,13}$. Gejala depresi dapat dinilai mulai dari ketidakseimbangan emosional, fisiologis, psikomotorik, dan psikologis ${ }^{6}$. Stigma yang terjadi pada perawat terkait dengan pekerjaannya yang selalu kontak dengan pasien COVID-19 dan harus mengasingkan diri atau menyendiri ${ }^{14}$. Perawat juga mengalami diskriminasi terkait stres kerja seperti jam kerja yang panjang, harus menggunakan alat pelindung diri yang ketat, dan pengalaman bekerja di ruangan COVID-19. Selain itu, diskriminasi juga terjadi karena kurangnya dukungan dari keluarga dan rekan kerja dalam bekerja merawat pasien COVID-19 ${ }^{15}$. Hal ini terjadi karena perawat memiliki risiko tinggi menularkan kepada orang lain dan lingkungan sekitarnya.

3. Stres

Stres akut yang dialami perawat terkait dengan masalah keamanan pribadi, ketakutan menularkan virus ke anggota keluarga dan kematian pasien yang dirawat. Selain itu, juga terdapat rasa lelah akibat bertambahnya jumlah jam kerja, kurangnya alat pelindung diri saat merawat pasien COVID-19 dan merasa tidak nyaman selama berada di ruang isolasi ${ }^{4}$. Faktor alat pelindung diri (APD) juga mempengaruhi stres yang dialami perawat. Penggunaan APD yang tidak memadai juga menjadi salah satu faktor penyebab terjadinya infeksi ${ }^{3,10}$. Selain menjadi faktor penyebab infeksi, penggunaan APD juga dapat menimbulkan kecemasan bagi tenaga medis ${ }^{4}$. Gangguan tidur atau insomnia dan gangguan jiwa lainnya yang dialami perawat timbul akibat seringnya kontak langsung dengan pasien Covid- 19 dan 
bekerja sesuai jam kerja biasanya setiap shift (4-12 jam). Keadaan ini lebih sering dialami oleh perawat baru karena perawat baru belum memiliki banyak pengalaman dalam menangani pasien infeksi ${ }^{11,4}$.

\section{Insomnia}

Gangguan tidur atau insomnia dan gangguan jiwa lainnya yang dialami perawat timbul akibat seringnya kontak langsung dengan pasien Covid- 19 dan bekerja sesuai jam kerja biasanya setiap shift (4-12 jam). Keadaan ini lebih sering dialami oleh perawat baru karena perawat baru belum memiliki banyak pengalaman dalam menangani pasien infeksi ${ }^{11,4}$.

\section{PEMBAHASAN}

Pengalaman adalah cara yang diperoleh dengan belajar melalui kegiatan atau hal-hal yang dilakukan secara langsung oleh individu. Pengalaman merawat pasien COVID-19 merupakan pengalaman yang membuat stres, cemas, dan pertama bagi perawat di seluruh dunia. Kondisi yang terjadi seperti ini yang telah ditetapkan oleh WHO membuat pelayanan yang ada di bidang kesehatan terutama mengalami kecemasan yang berlebihan dan kemampuan mengelola stres yang dapat timbul sehingga perawat dapat mengatasi masalah stresor dalam dirinya ${ }^{11}$.

Risiko yang paling terlihat adalah aspek keselamatan tenaga kesehatan, terutama yang berada di garda terdepan, yang sangat rentan terpapar COVID-19 dan berisiko mengancam jiwa. Tercatat lebih dari 100 dokter dan ratusan tenaga medis lainnya meninggal dunia akibat terinfeksi COVID-19 saat menjalankan tugas pelayanan kesehatan. Selain aspek keselamatan dan perlindungan dari infeksi, risiko lain yang berpotensi mempengaruhi kualitas hidup dan produktivitas layanan medis kami adalah aspek kesehatan mental, termasuk risiko sindrom burnout atau kelelahan mental. Tenaga kesehatan berpotensi terkena tingkat stres yang sangat tinggi, tetapi tidak ada aturan atau kebijakan yang dapat melindungi mereka dari perspektif kesehatan mental. Penelitian yang dilakukan tim peneliti dari Program Studi Magister Kedokteran Kerja Fakultas Kedokteran Universitas Indonesia (MKK FKUI) menunjukkan fakta bahwa sebanyak 83\% tenaga kesehatan di Indonesia pernah mengalami burnout syndrome sedang dan berat, yaitu secara psikologis berisiko mengganggu kualitas hidup dan produktivitas kerja di bidang pelayanan kesehatan.Menurut Ketua Tim Peneliti, Dr. dr. Dewi Soemarko, MS, SpOK, penelitian ini juga menemukan fakta bahwa Dokter Umum di Indonesia yang menjalankan tugas pelayanan medis di garda terdepan selama Pandemi COVID-19 memiliki risiko 2 kali lebih besar untuk mengalami burnout syndrome.

Tingginya risiko menderita burnout syndrome akibat terpapar stres yang luar biasa berat di fasilitas kesehatan selama pandemi ini dapat berdampak jangka panjang terhadap kualitas pelayanan medis karena para tenaga kesehatan tersebut dapat merasa tertekan, kelelahan yang ekstrim bahkan merasa kurang kompeten dalam melaksanakan tugas. Tugas mereka, dan ini tentu berdampak. tidak baik untuk upaya kita melawan COVID-19. Upaya yang dilakukan dalam menangani masalah psikologis tenaga kesehatan khususnya perawat perlu dilakukan intervensi psikologis. Intervensi psikologis dilakukan dalam bentuk tim hotline bantuan psikologis.

Tim yang dibentuk ini bertugas memberikan pembinaan dan pengawasan kepada tenaga kesehatan. Langkah intervensi pertama adalah menyediakan tempat istirahat sementara bagi rumah sakit dalam proses isolasi mandiri. Kedua, memberikan pengetahuan terkait penyakit, langkah-langkah penggunaan alat pelindung diri dan melakukan pelatihan sebelum menangani pasien COVID-19. Ketiga 
rumah sakit tersebut mengembangkan protokol kesehatan mendetail terkait pengelolaan alat pelindung diri selama pandemi COVID-19. Keempat, cara rileks yang baik untuk mengurangi stres psikologis ${ }^{16,2}$. Hasil penelitian menunjukkan bahwa dengan intervensi

\begin{tabular}{lll}
\hline No & $\begin{array}{c}\text { Author, Year, } \\
\text { Country }\end{array}$ & \multicolumn{1}{c}{ Title } \\
\hline 1 & (Li et al., 2020) $^{\text {China }}{ }^{1}$ & Coping Strategies as Predictors of \\
& & Anxiety: Exploring Positive \\
& & Experience of Chinese University \\
& & in Health Education in COVID- \\
& & 19 Pandemic
\end{tabular}

2. (Han et al., 2020) China $^{18}$
Anxiety and Depression of Nurses in a North West Province in China During the Period of Novel Coronavirus Pneumonia Outbreak psikologis yang dilakukan, lebih dari 100 tenaga kesehatan garda terdepan dapat beristirahat di tempat kerja yang telah disediakan, merasa lebih tenang, nyaman dan memiliki respon yang baik selama merawat pasien COVID-19 ${ }^{17}$.

Research design Findings

A cross- The emergence of
sectional survey psychological anxiety was prevalent throughout the previous studies, with rates ranging from $3.2 \%$ to $12.6 \%$,

$\begin{array}{ll}\text { A cross- } & \text { Nurses dealing with the } \\ \text { sectional survey } & \text { COVID-19 outbreak are at } \\ & \text { risk for anxiety and } \\ & \text { depression. Demographic } \\ & \text { background, psychosocial } \\ & \text { factors, and work-related } \\ & \text { factors predict } \\ & \text { psychological responses. } \\ & \text { Family responsibilities and } \\ & \text { women's burdens may } \\ & \text { explain the higher levels of } \\ & \text { anxiety and depression } \\ & \text { among nurses with these } \\ & \text { obligations compared to } \\ & \text { those without. }\end{array}$

A cross-
3. (Temsah et al., The psychological impact of Quantitative study 2020) $\operatorname{Arabia}^{8}$
COVID-19 pandemic on health care Workers in a MERS-CoV endemic country.
There are psychological disorders in nurses such as anxiety and worry. For the level of anxiety experienced there are: mild anxiety, moderate anxiety, high anxiety, very high anxiety

\begin{tabular}{|c|c|c|c|}
\hline $\begin{array}{l}\text { (Cai et al., 2020) } \\
\text { New York }\end{array}$ & $\begin{array}{l}\text { The Psychological Impact of } \\
\text { COVID-19 on Hospital Trainees } \\
\text { in a New York City Hospital }\end{array}$ & survey demographic & $\begin{array}{l}\text { Trainees face immense } \\
\text { isolation, exhaustion, and } \\
\text { fear of contracting and } \\
\text { transmitting COVID-19 }\end{array}$ \\
\hline
\end{tabular}

\begin{tabular}{lll}
\hline 5. $\begin{array}{ll}\text { (H. Wang et al., } \\
\text { 2020) China }{ }^{13}\end{array}$ & $\begin{array}{l}\text { The psychological impact of } \\
\text { COVID-19 pandemic on medical }\end{array}$ \\
& $\begin{array}{l}\text { staff in Guangdong, China: } a \\
\text { cross- sectional study. }\end{array}$ & $\begin{array}{l}\text { Psychological responses } \\
\text { that occurred to nurses } \\
\text { during the COVID-19 }\end{array}$ \\
& $\begin{array}{l}\text { pandemic such as anxiety } \\
(55.4 \%) \text { and depression } \\
(43.6 \%)\end{array}$
\end{tabular}


6. (Hong et al., Immediate psychological impact Cross-sectional study 2020) China ${ }^{15} \quad$ on nurses working at
42 government-
designated hospitals during
COVID-19 outbreak in China: A
cross-sectional study

Psychological impacts that occur on nurses such as symptoms of depression to wanting to commit suicide, anxiety, and stigmatization due to discrimination.

\section{7. (Hu et al., 20) China $^{6}$

\author{
Frontline nurses' \\ burnout, anxiety, depression, and fear \\ statuses and their associated factors \\ during the COVID-19 outbreak in \\ Wuhan, China: A large-scale cross- \\ sectional study \\ A large-scale \\ correlational study
} descriptive,
8. (Sun et al., 2020) A qualitative study on the Qualitative study China $^{3}$ psychological experience of caregivers of COVID- 19 patients.

$\begin{array}{ll}\text { A large-scale } & \text { Psychological problems for } \\ \text { crosssectional, } & \text { nurses while caring for } \\ \text { descriptive, } & \text { COVID-19 patients such as } \\ \text { correlational study } & \text { anxiety, depression and fear } \\ & \text { due to COVID-19. }\end{array}$
due to COVID-19.

Psychological experiences for nurses such as fear of being infected, worrying about infecting family members, and anxiety
9. (Shen, Zou, Psychological stress of ICU nurses in Qualitative study Zhong, Yan, \& the time of COVID-19 Li, 2020) China ${ }^{19}$
10. (Elhadi et al., Psychological status of healthcare cross-sectional study 2020) Libya ${ }^{14}$ workers during the civil war and COVID19 pandemic: A cross- sectional study

Psychological problems experienced by nurses such as anxiety, worrying about being infected and transmitting it to the family, long-term fatigue, depression.

Psychological problems in nurses such as symptoms of depression, anxiety and stigma experienced while caring for COVID-19 patients.

\begin{tabular}{lrl}
\hline 11. & $\begin{array}{l}\text { (Aksoy } \\
\text { Koçak, }\end{array}$ & Psychological effects of nurses and Quantitative \\
Turkey & midwives due to COVID-19 outbreak: & The case of Turkey
\end{tabular}
Koçak, The case of Turkey
Psychological impacts experienced by nurses during the COVID-19 pandemic such as anxiety (36.3\%), discomfort $(31.3 \%)$ and fear (19.4\%).

\begin{tabular}{|c|c|c|c|c|}
\hline 12. & $\begin{array}{l}\text { (Shechter et al., } \\
\text { 2020) USA }{ }^{9}\end{array}$ & $\begin{array}{l}\text { Psychological distress, coping } \\
\text { behaviors, and } \\
\text { preferences for support among } \\
\text { New York healthcare workers during } \\
\text { the COVID-19 pandemic. }\end{array}$ & Cross-sectional study & $\begin{array}{l}\text { Psychological disorders in } \\
\text { nurses such as anxiety } \\
(33 \%) \text {, acute stress }(57 \%) \text {, } \\
\text { and depressive symptoms } \\
(48 \%) \text {. }\end{array}$ \\
\hline 13. & $\begin{array}{l}\text { (Juan et al., } \\
\text { 2020) China }{ }^{22}\end{array}$ & $\begin{array}{l}\text { Psychological distress surveillance } \\
\text { and related impact analysis of } \\
\text { hospital staff during the COVID-19 } \\
\text { epidemic in Chongqing, China. }\end{array}$ & Cross-sectional study & $\begin{array}{l}\text { Symptoms of } \\
\text { psychological distress on } \\
\text { nurses included }(33.3 \%) \text {, } \\
\text { anxiety }(31.6 \%), \quad \text { and } \\
\text { depression }(29.6 \%) \text {. }\end{array}$ \\
\hline 14. & $\begin{array}{l}\text { (Lu, Wang, Lin, } \\
\& \quad \mathrm{Li}, \quad 2020) \\
\text { China }^{10}\end{array}$ & $\begin{array}{l}\text { Psychological status of medical } \\
\text { workforce during the COVID-19 } \\
\text { pandemic: A cross- sectional study. }\end{array}$ & Cross-sectional study & $\begin{array}{l}\text { Psychological disorders } \\
\text { experienced by nurses such } \\
\text { as fear, anxiety and } \\
\text { symptoms of depression. }\end{array}$ \\
\hline
\end{tabular}


15. (Lee et al., 2020) Psychological distress during the Singapore ${ }^{21}$ COVID-19 pandemic amongs Anaesthesiologists and nurses.

\begin{tabular}{lll}
\hline 16. & (Opan & Phenomenological Study: Experience \\
Sukiman.,2020) & of Nurses in Handling Patients With \\
Indonesia & Covid-19 in Hospitals in Jakarta Year \\
& 2020
\end{tabular}

17. Koh, Hegney \& “Nurses' perceptions of risk from Qualitative Drury $(2012)^{22} \quad$ emerging respiratory

infectious diseases: a Singapore study"
Cross-sectional study Psychological stress on nurses such as depression $(50.4 \%)$ and anxiety $(44.6 \%)$.

Qualitative Response to psychological disorders

shown by the nurse is an emotional change in the form of a response to anxiety and fear. This change happened due to separation from family, unusual situation, increased exposure to coronavirus,

fear of contagion, and feelings of failure in the face of poor prognosis and inadequate technical means sufficient to help the patient.

Risk of infection,
transmission to family members, the vulnerability of their work and restrictions on personal freedom have been reported as concerns for nurses.

$\begin{array}{llll}\text { 18. Kim (2018) } & \text { Nurses' experiences of care for patients } \\ \text { South Korea Middle East respiratory } & \text { Qualitative study } \\ & \text { syndrome- coronavirus in South Korea }\end{array}$

Physical exhaustion, psychological helplessness, health threats, lack of knowledge, and interpersonal ignorance under threat of epidemic disease

cause a large number of negative emotions such as fear, anxiety, and helplessness.

19. Niuniu, et al A qualitative study on the psychological Qualitative study $\begin{array}{ll}(2020)^{23} & \text { experience } \\ \text { COVID- } 19 \text { patient }\end{array}$ The nurses' fear peaked when they entered negative pressure wards also expressed concern about patients in isolated settings with relatively few and many caregivers patient.
Nurses choose to self- isolate as a protection strategy for family members. 


\section{KESIMPULAN DAN SARAN}

Di tengah pandemi Covid-19, perawat harus memberikan pelayanan yang optimal terkait tindakan pencegahan dan pengendalian infeksi demi keselamatan dirinya dan masyarakat. Hal ini menciptakan tekanan psikologis yang terjadi pada perawat saat merawat pasien Covid-19. Perawat yang menangani pasien Covid-19 cenderung mengalami kecemasan, depresi, dan insomnia yang lebih tinggi dibandingkan dengan yang tidak. Persepsi perawat yang merasa berisiko terpapar Covid-19 secara signifikan berkaitan dengan masalah psikologis seperti gangguan kecemasan, depresi, dan insomnia. Sehingga kesehatan mental perawat sebagai garda terdepan saat pandemi sangat penting untuk diperhatikan dan meminimalkan faktor situasional dan memberikan intervensi sesuai kebutuhan psikologis yang dapat menurunkan tingkat atau gejala kesehatan mental perawat.

Perawat sebagai tenaga kesehatan garda terdepan yang mempynyai peran penting dalam menangani pasien Covid-19 dengan tanggung jawab yang sangat besar. Tuntutan yang banyak membuat para perawat mengalami tekanan yang begitu sangat besar, sehingga membuat psikologis mereka menjadi terganggu dan sangat membutuhkan dukungan dari orangorang sekitar untuk dapat terus menjalankan pekerjaan. Dengan memberikan dukungan

\section{UCAPAN TERIMAKASIH}

Terimakasih penulis ucapan kepada semua pihak yang telah membantu dalam penyelesaian penelitian ini. kepada perawat dapat membangun semngat perawat untuk menjalani pekerjaan yang mereka lakukan dengan perasaan gembira tanpa tekanan walaupun dengan resiko yang berat sekalipun. Perlu adanya pendampingan bagi perawat dalam mengelola tingkat psikologis agar tidak mengganggu dalam mereka bekerja, dengan demikian diharapkan hal tersebut dapat setidaknya mengurangi tingkat pengalaman psikologis yang buruk yang mereka alami.

\section{DAFTAR PUSTAKA}

1. Li Y, Peng J. Coping Strategies as Predictors of Anxiety: Exploring Positive Experience of Chinese University in Health Education in COVID-19 Pandemic. Creat Educ. 2020;11(5):735-750. doi:10.4236/CE.2020.115053

2. Yu Tao X, Yuan Y, Wen L, et al. Timely mental health care for the 2019 novel coronavirus outbreak is urgently needed. The lancet Psychiatry. 2020;7(3):228-229. doi:10.1016/S2215-0366(20)30046-8

3. Niuniu S, Luoqun W, Suling S, et al. A qualitative study on the psychological experience of caregivers of COVID-19 patients. Am J Infect Control. 2020;48(6):592-598. doi:10.1016/J.AJIC.2020.03.018

4. Haozheng $\mathrm{C}$, Baoren $\mathrm{T}$, Jing $\mathrm{M}$, et al. Psychological Impact and Coping Strategies of Frontline Medical Staff in Hunan Between January and March 2020 During the Outbreak of Coronavirus Disease 2019 (COVID-19) in Hubei, China. Med Sci Monit. 2020;26. doi:10.12659/MSM.924171

5. Gordon J G A, Steven T. How health anxiety influences responses to viral outbreaks like COVID-19: What all decision-makers, health authorities, and health care professionals need to know. $J$ Anxiety Disord. 2020;71. doi:10.1016/J.JANXDIS.2020.102211

6. $\mathrm{Hu} \mathrm{D}$, Kong $\mathrm{Y}$, Li W, et al. Frontline nurses' burnout, anxiety, depression, and fear statuses and their associated factors during the COVID-19 outbreak in Wuhan, China: A large-scale cross-sectional study. EClinicalMedicine.

2020;24. doi:10.1016/J.ECLINM.2020.100424

7. Lu W, Wang H, Lin Y, Li L. Since January 2020 Elsevier has created a COVID-19 resource centre with free information in English and Mandarin on the novel coronavirus COVID- 19 . The COVID-19 resource centre is hosted on Elsevier 
Connect, the company' s public news and information. Psychiatry Resaerch.

8. Temsah MH, Al-Sohime F, Alamro N, et al. The psychological impact of COVID19 pandemic on health care workers in a MERS-CoV endemic country. $J$ Infect Public Health. 2020;13(6):877-882. doi:10.1016/J.JIPH.2020.05.021

9. Shechter A, Diaz F, Moise N, et al. Psychological distress, coping behaviors, and preferences for support among New York healthcare workers during the COVID-19 pandemic. Gen Hosp Psychiatry. 2020;66:1. doi:10.1016/J.GENHOSPPSYCH.2020.0 6.007

10. Lu W, Wang H, Lin Y, Li L. Psychological status of medical workforce during the COVID-19 pandemic: A cross-sectional study. Psychiatry Res. 2020;288:112936. doi:10.1016/J.PSYCHRES.2020.112936

11. Wang W, Huang W, Liu X, Hennessy A D. Psychological impact of mandatory COVID-19 quarantine on small business owners and self-employed in China. Curr Psychol. Published online 2021. doi:10.1007/S12144-021-01983-2

12. Juan Y, Yuanyuan C, Qiuxiang Y, et al. Psychological distress surveillance and related impact analysis of hospital staff during the COVID-19 epidemic in Chongqing, China. Compr Psychiatry. 2020;103:152198.

doi:10.1016/J.COMPPSYCH.2020.15219 8

13. Wang H, Huang D, Huang H, et al. The psychological impact of COVID-19 pandemic on medical staff in Guangdong, China: a cross-sectional study. Psychol Med. Published online 2020. doi:10.1017/S0033291720002561

14. Elhadi M, Msherghi A. Mental health of surgeons during the COVID-19 pandemic: An urgent need for intervention. Surg (United States). 2020;169(2):477-478. doi:10.1016/J.SURG.2020.08.035

15. Hong $\mathrm{S}, \mathrm{Ai} \mathrm{M}, \mathrm{Xu} \mathrm{X}$, et al. Immediate psychological impact on nurses working at 42 government-designated hospitals during COVID-19 outbreak in China: A cross-sectional study. Nurs Outlook. 2021;69(1):6-12. doi:10.1016/J.OUTLOOK.2020.07.007

16. Chen Q, Liang M, Li Y, et al. Mental health care for medical staff in China during the COVID-19 outbreak. The lancet Psychiatry. 2020;7(4):e15-e16. doi:10.1016/S2215-0366(20)30078-X

17. Kang L, Li Y, Hu S, et al. The mental health of medical workers in Wuhan, China dealing with the 2019 novel coronavirus. The lancet Psychiatry. 2020;7(3):e14. doi:10.1016/S22150366(20)30047-X

18. Han L, Wong FKY, She DoLM, et al. Anxiety and Depression of Nurses in a North West Province in China During the Period of Novel Coronavirus Pneumonia Outbreak. J Nurs Scholarsh an Off Publ Sigma Theta Tau Int Honor Soc Nurs. 2020;52(5):564-573. doi:10.1111/JNU.12590

19. Shen X, Zou X, Zhong X, Yan J, Li L. Psychological stress of ICU nurses in the time of COVID-19. Crit Care 2020241. 2020;24(1):1-3. doi:10.1186/S13054-02002926-2

20. Aksoy YE, Koçak V. Psychological effects of nurses and midwives due to COVID-19 outbreak: The case of Turkey. Arch Psychiatr Nurs. 2020;34(5):427-433. doi:10.1016/J.APNU.2020.07.011

21. Lee MCC, Thampi S, Chan HP, et al. Psychological distress during the COVID19 pandemic amongst anaesthesiologists and nurses. $\mathrm{Br} J$ Anaesth. 2020;125(4):e384-e386. doi:10.1016/J.BJA.2020.07.005

22. Koh Y, Hegney D, Drury V. Nurses' perceptions of risk from emerging respiratory infectious diseases: A Singapore study. Int $J$ Nurs Pract. 2012;18(2):195-204. doi:10.1111/J.1440172X.2012.02018.X

23. N S, L W, S S, et al. A qualitative study on the psychological experience of caregivers of COVID-19 patients. Am J Infect Control. 2020;48(6):592-598. doi:10.1016/J.AJIC.2020.03.018 
24. Lam KK, Hung SYM. Perceptions of emergency nurses during the human swine influenza outbreak: a qualitative study. Int Emerg Nurs. 2013;21(4):240-246. doi:10.1016/J.IENJ.2012.08.008 